Old Dominion University

ODU Digital Commons

$1-2020$

\title{
Abiotic Formation of Dissolved Organic Sulfur in Anoxic Sediments of Santa Barbara Basin
}

\author{
Hussain A. Abdulla \\ David J. Burdige \\ Old Dominion University, dburdige@odu.edu \\ Tomoko Komada
}

Follow this and additional works at: https://digitalcommons.odu.edu/oeas_fac_pubs

Part of the Geochemistry Commons, Geophysics and Seismology Commons, and the Oceanography Commons

\section{Original Publication Citation}

Abdulla, H. A., Burdige, D. J., \& Komada, T. (2020). Abiotic formation of dissolved organic sulfur in anoxic sediments of Santa Barbara Basin. Organic Geochemistry, 139, 103879. doi:10.1016/ j.orggeochem.2019.05.009 


\title{
Abiotic formation of dissolved organic sulfur in anoxic sediments of Santa Barbara Basin
}

\author{
Hussain A. Abdulla ${ }^{a, *}$, David J. Burdige ${ }^{b}$, Tomoko Komada ${ }^{c}$ \\ ${ }^{a}$ Department of Physical and Environmental Sciences, Texas AEM University-Corpus Christi, 6300 Ocean Drive, Corpus Christi, TX 78412, USA \\ b Department of Ocean, Earth and Atmospheric Sciences, Old Dominion University, 4600 Elkhorn Ave., Norfolk, VA 23529, USA \\ ${ }^{\mathrm{c}}$ Estuary Er Ocean Science Center, San Francisco State University, 3150 Paradise Drive, Tiburon, CA 94920, USA
}

\section{A R T I C L E I N F O}

\section{Article history:}

Received 24 November 2018

Received in revised form 28 March 2019

Accepted 31 May 2019

Available online 10 June 2019

\section{Keywords:}

Abiotic sulfurization

Dissolved organic matter

Dissolved organic sulfur

Fourier transform ion cyclotron resonance

mass spectrometry

Carboxyl-rich alicyclic molecules

Pore water

Anoxic sediment

\begin{abstract}
A B S T R A C T
Sulfurization has been found to enhance organic matter preservation and petroleum formation in marine sediments. However, we do not yet have a comprehensive understanding of sulfurization mechanisms. In this study, we investigated several possible mechanisms of dissolved organic sulfur (DOS) formation in the top $4.5 \mathrm{~m}$ of anoxic sediments of Santa Barbara Basin (SBB), California Borderland. Using Fourier Transform Ion Cyclotron Resonance Mass Spectrometry (FTICR-MS), we identified chemical formulas of potential dissolved organic matter (DOM) precursors to these DOS compounds. We also examined how the formulas of abiotically formed DOS changed as a function of depth across a major redox gradient.

Results show that abiotic nucleophilic addition reactions involving bisulfide $\left(\mathrm{HS}^{-}\right)$and polysulfide $\left(\mathrm{HS}_{\mathrm{x}}^{-}\right)$are the major sulfurization pathways that form DOS in anoxic pore waters of SBB sediments. We identified 2124 unique DOS formulas that could be generated from the addition of $\mathrm{HS}^{-}$and $\mathrm{HS}_{\mathrm{x}}^{-}$to 2203 DOM formulas, and this accounted for $\sim 70 \%$ of all DOS formulas detected in these pore waters. Examining the DOM formulas that served as reactants in the abiotic sulfurization reactions, we found that $64 \%$ contained only carbon, hydrogen, and oxygen (CHO formulas) while the remainder (34\%) included nitrogen (DON formulas). Our results revealed high reactivity toward sulfurization among many of the $\mathrm{CHO}$ and DON formulas that have $\mathrm{H} / \mathrm{C}$ and $\mathrm{O} / \mathrm{C}$ elemental ratios that overlap with those of carboxylrich alicyclic molecules (CRAM). This specific class of formulas could play an important role in the formation of organic sulfur compounds in sulfidic marine ecosystems, and in the formation of sulfur-containing protokerogen in marine sediments. Our results further suggest that anoxic sediments are a source of DOS compounds to the oceans.
\end{abstract}

Published by Elsevier Ltd.

\section{Introduction}

Sulfurization has been shown to enhance organic matter preservation and protokerogen formation at low temperatures in marine sediments (e.g. Valisolalao et al., 1984; Sinninghe Damsté and De Leeuw, 1990; Krein and Aizenshtat, 1995; Nelson et al., 1995; Putschew et al., 1998; van Dongen et al., 2003). Also, when considering the role of the sulfur cycle in the evolution of atmospheric $\mathrm{O}_{2}$ concentration over geologic time, the importance of organic sulfur burial may be greater than previously thought (Werne et al., 2004). The relative abundance of organic sulfur in sedimentary settings varies widely, from 1 to $80 \%$ of the total reduced sulfur (Anderson and Pratt, 1995; Werne et al., 2003), and appears to

\footnotetext{
* Corresponding author.

E-mail address: hussain.abdulla@tamucc.edu (H.A. Abdulla).
}

be largely controlled by the availability of both reduced inorganic sulfur species and reactive iron (Canfield et al., 1992, 1996; Eglinton and Repeta, 2003). However, we do not yet have a comprehensive understanding of sulfurization mechanisms.

Assimilatory sulfate reduction represents one source of sedimentary organic sulfur, where microbes reduce sulfate to biosynthesize organic sulfur compounds such as methionine or cysteine (e.g. Kim and Gadd, 2008). However, the sulfur content of microbial detritus is relatively low (Sinninghe Damsté and Orr, 1990; Eglinton et al., 1994), and in many sedimentary settings this does not account for all of the organic sulfur that is buried (Filley et al., 2002). Several lines of evidence indicate that abiotic sulfurization of organic matter by bisulfide $\left(\mathrm{HS}^{-}\right)$and polysulfide $\left(\mathrm{HS}_{\mathrm{x}}^{-}\right)$ represents another formation mechanism for sedimentary organic sulfur. For example, several studies have detected compounds that result from sulfurization of many lipids (e.g. $C_{28}$-dialkylthiophene; $\mathrm{C}_{37}$-2,6-di-n-alkylthianaes) during early diagenesis in anoxic to 
mixed-redox sediments (e.g. Valisolalao et al., 1984; Sinninghe Damsté et al., 1989; Wakeham et al., 1995). Other laboratory studies have examined the abiotic formation of 3-mercaptopropionic acid from acrylic acid (Vairavamurthy and Mopper, 1987) and the sulfurization of phytol compounds (De Graaf et al., 1992). However, these studies examined the abiotic sulfurization of a small number of targeted compounds, and therefore do not provide a comprehensive understanding of the role these mechanisms may play in the formation and burial of complex mixtures of organic sulfur compounds in marine sediments (Zhu et al., 2014). Furthermore, while the above studies contribute to the understanding of the formation of reduced organic sulfur species, they do not explain the formation and burial of oxidized organic sulfur species (e.g. sulfones) in anoxic sediments (Eglinton et al., 1994; Zhu et al., 2014).

Analysis of dissolved organic matter (DOM) by ultrahigh resolution mass spectrometry, such as Fourier Transform Ion Cyclotron Resonance Mass Spectrometry (FTICR-MS), provides the ability to measure a small mass differences of $3.37 \mathrm{mDa}$ or less between two possible molecular formulas. Thus mass differences are required to accurately assign sulfur containing organic molecular formulas from other isobaric ions (for examples, formulas that contain either $\mathrm{S}$ or $\mathrm{O}_{2}, \mathrm{SH}_{4}$ or $\mathrm{C}_{3}$ ) (Koch et al., 2007; Reemtsma, 2009). Recently, several studies have utilized FTICR-MS to identify dissolved organic sulfur compounds in sediment pore waters, and to investigate sulfurization mechanisms. Schmidt et al. (2009) observed higher abundance of organic sulfur compounds in riverine sediment pore waters relative to continental shelf pore waters. Along the same lines, Seidel et al. (2014) showed an increase of the relative abundance of DOS formulas from recharge to discharge zone of intertidal creek bank sediment pore waters. Both Schmidt et al., (2009) and Seidel et al., (2014) attributed this to greater rates of diagenetic sulfurization in sediments. It also appears that there is a higher abundance of DOS formulas in anoxic (Schmidt et al., 2009) versus oxic (Rossel et al., 2016) sediment pore waters, consistent with higher production of organic sulfur compounds in anoxic relative to oxic sediments (Werne et al., 2004 and references within). Through laboratory experiments, Melendez-Perez et al. (2018) proposed that the addition of sulfide species to lignin-like $\mathrm{CHO}$ compounds (with sediment minerals acting as catalysts) could serve as a possible pathway for the formation of polyoxygenated organic sulfur compounds (CHOS). To identify DOS formulas that are potentially formed in shallow hydrothermal systems through abiotic sulfurization reactions, Gomez-Saez et al. (2016) used FTICR-MS to track nine possible sulfur addition reactions that involve addition or removal of hydrogen and/or oxygen atoms (a total of 27 potential sulfurization reactions). The same approach has been used to verify experimentally the occurrence of abiotic sulfurization under sulfidic conditions of natural DOM, and DOM directly derived from algal cultures (Pohlabeln et al., 2017). This approach has also been used to follow the photochemical alteration of DOS from sulfidic pore water (Gomez-Saez et al., 2017).

To build on these past observations we carried out FTICR-MS analyses of pore water samples collected as a function of depth in Santa Barbara Basin (SBB) sediments, where we have previously studied DOM production and turnover (Burdige et al., 2016a,b; Komada et al., 2016; Abdulla et al., 2018). The main aim of this study was to improve our understanding of DOS formation and cycling within the context of early diagenetic processes in these sediments (including the transition from sulfate reduction to methanogenesis), with an emphasis on examining abiotic sulfurization through nucleophilic addition reactions of both bisulfide $\left(\mathrm{HS}^{-}\right)$and polysulfide $\left(\mathrm{HS}_{\mathrm{x}}^{-}\right)$. Our specific objectives were to investigate: (1) the formation mechanisms of dissolved organic sulfur (DOS) compounds in pore waters, and (2) the chemical formulas of potential DOM reactants in the abiotic formation of organosulfur compounds.

\section{Materials and methods}

\subsection{Sampling and study site}

Sediment cores were recovered from the center of SBB $\left(34.223^{\circ} \mathrm{N}, 119.983^{\circ} \mathrm{W}, 590 \mathrm{~m}\right.$ water depth) using a gravity corer and a multicorer onboard $R / V$ Robert Gordon Sproul in August 2012, and $R / V$ New Horizon in August 2013, and pore water samples were extracted from these cores as described previously (Komada et al., 2016). Our previous work on these sediment cores indicates that sulfate $\left(\mathrm{SO}_{4}^{2-}\right)$ is consumed by organoclastic $\mathrm{SO}_{4}^{2-}$ reduction and anaerobic oxidation of methane (AOM), leading to the formation of a sulfate-methane transition zone (SMTZ) at $\sim 125$ cm (Fig. 1; Komada et al., 2016; Burdige et al., 2016a,b). Dissolved organic carbon (DOC) concentrations increase with sediment depth from $0.28 \mathrm{mM}$ at the surface to over $5 \mathrm{mM}$ at the base of the core (Komada et al., 2016; Burdige et al., 2016a). The shape of the DOC profile and results from a DOC reactiontransport model indicate that there is continuous and steady accumulation of DOC with depth in these pore waters (Burdige et al., 2016a).

\subsection{Total dissolved sulfide $\left(\sum \mathrm{H}_{2} \mathrm{~S}\right)$ measurements}

Pore water samples for total dissolved sulfide $\left(\sum \mathrm{H}_{2} \mathrm{~S}=\left[\mathrm{H}_{2} \mathrm{~S}\right]\right.$ $\left.+\left[\mathrm{HS}^{-}\right]+\left[\mathrm{S}^{2-}\right]\right)$ analysis were fixed onboard ship by adding pore water to an $\mathrm{N}_{2}$-degassed solution containing $5 \mathrm{mM} \mathrm{ZnCl} 2$ and $10 \mathrm{mM} \mathrm{NaOH}$ (Ingvorsen and Jorgensen, 1979) in a $10 \mathrm{ml}$ serum bottle. At the basic pH of this "fixing" solution, all dissolved inorganic sulfide precipitates out as $\mathrm{ZnS}$. The head space was then degassed with $\mathrm{N}_{2}$ and the bottle was crimp sealed with plug-style

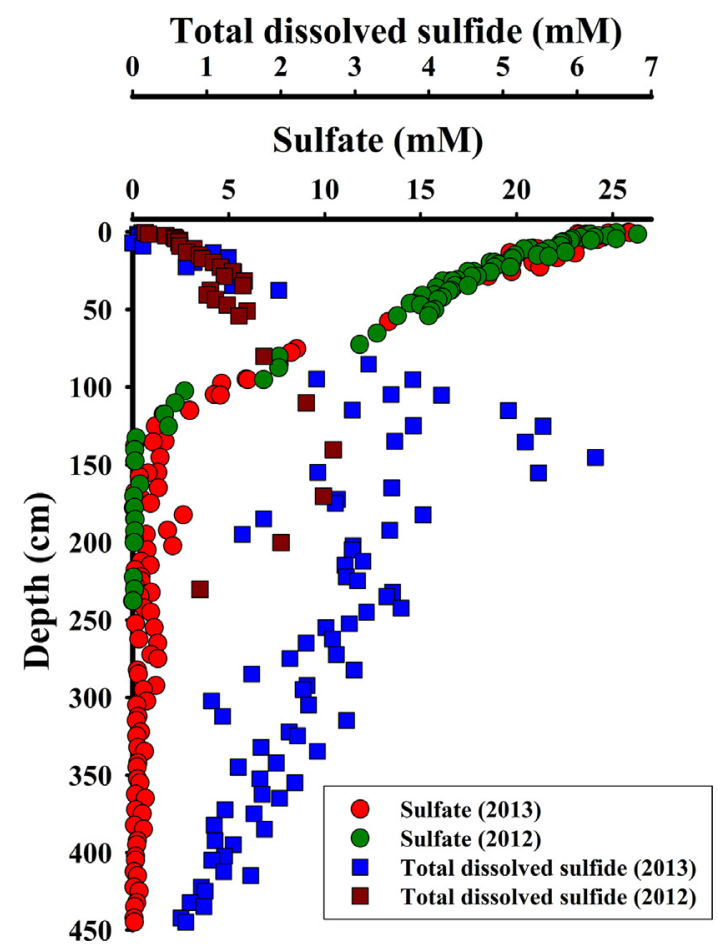

Fig. 1. Pore water depth profiles of sulfate and total dissolved sulfide obtained from multiple multicores and gravity cores collected in SBB in 2012 and 2013. The sulfate data were adopted with modification from Komada et al. (2016). 
stoppers, and refrigerated. Upon returning to the shore-based lab, $\sum \mathrm{H}_{2} \mathrm{~S}$ was determined spectrophotometrically using the methylene blue technique (Cline, 1969). All reagents were added directly to the serum bottle containing the $\mathrm{ZnS}$ suspension. For pore water samples near the sediment surface (upper $10 \mathrm{~cm}$ ) where sulfide levels are low, $1 \mathrm{ml}$ of pore water was added to $9 \mathrm{ml}$ of the fixing solution, whereas for deeper samples (with higher sulfide levels) $0.1 \mathrm{ml}$ pore water was added to $10 \mathrm{ml}$ of the fixing solution.

\subsection{FTICR-MS analysis}

Pore water samples for FTICR-MS analysis were immediately flame-sealed without acidification under a stream of ultra-highpurity $\mathrm{N}_{2}$ and stored under refrigeration at $4{ }^{\circ} \mathrm{C}$. In total, 28 pore water samples from multiple cores that spanned a depth range of $0.25 \mathrm{~cm}$ to $432 \mathrm{~cm}$ were analyzed using the method described in detail in Abdulla et al. (2018). In brief, pore water samples were prepared for mass spectrometric analysis using PPL solid phase extraction cartridges according to the procedure recommended by Dittmar et al. (2008). Samples were analyzed with a Bruker Daltonics 12 T Apex Qe FTICR-MS operating in negative ion mode, and were continuously infused into the instrument with an Apollo II ESI ion source at a rate of $120 \mu \mathrm{h} \mathrm{h}^{-1}$. All mass spectra were externally calibrated with a polyethylene glycol standard and internally calibrated using naturally present fatty acids (Sleighter et al., 2008). A signal to noise ratio $(S / N) \geq 3$ was used as the threshold for peak picking. The molecular formula for each peak was calculated using a molecular formula calculator (Molecular Formula Calc version 1.0 NHMFL, 1998) with the following parameters: $\mathrm{C}_{4-50^{-}}$ $\mathrm{H}_{4-200} \mathrm{O}_{0-20} \mathrm{~N}_{0-10} \mathrm{~S}_{0-3} \mathrm{P}_{0-3}$. Molecular formulas that are not chemically possible were removed according to the rules described in Abdulla et al. (2013). In summary, we applied a modified version of the rules set in Kind and Fiehn (2007), which requires that formulas satisfy the following inequalities: $\mathrm{H} / \mathrm{C}<2.50, \mathrm{O} / \mathrm{C} \leq 1.20$, $\mathrm{O} / \mathrm{P} \geq 3.00$, and $\mathrm{N} / \mathrm{C}<0.50$. All assigned formulas were further tested for the physical existence of chemical structures using LEWIS and SENIOR chemical rules, again according to Kind and Fiehn (2007). We also validated the molecular ${ }^{13} \mathrm{C}$ isotope and ${ }^{34} \mathrm{~S}$ isotope peaks (when they were detected above the $\mathrm{S} / \mathrm{N}$ threshold) and the chemical building block approach (e.g. $\mathrm{CH}_{2}$ homologies series) described by Koch et al. (2007). The calculated masses of the assigned formulas are all within $1.0 \mathrm{ppm}$ of the masses detected by FTICR-MS.

Double bond equivalents (DBE) for the assigned formulas were calculated according to the following equation:

$\mathrm{DBE}=1+\frac{1}{2} \sum_{i}^{i \max } N i(v i-2)$

where $N i$ is the number of atoms with valence $v i$. By using valences of $4,1,3,2,2$ and 5 for $\mathrm{C}, \mathrm{H}, \mathrm{N}, \mathrm{O}, \mathrm{S}$, and $\mathrm{P}$, respectively, DBE can be expressed as:

$\mathrm{DBE}=1+\mathrm{C}+\frac{1}{2} *(\mathrm{~N}+3 * \mathrm{P}-\mathrm{H})$

where $\mathrm{C}, \mathrm{N}, \mathrm{P}$ and $\mathrm{H}$ are the number of carbon, nitrogen, phosphorus and hydrogen atoms present. Note that with valences of 2,0 and $\mathrm{S}$ atoms drop out of Eq. (2). Assigned formulas were categorized into major organic compound classes according to their $\mathrm{H} / \mathrm{C}$ and $\mathrm{O} / \mathrm{C}$ ratios following Sleighter and Hatcher (2007), Abdulla et al. (2013) and Hertkorn et al. (2006) (Fig. S1).

The work presented here is based solely on the presence or absence of individual DOM formulas (i.e., peaks) in a spectrum and does not consider the relative magnitude of these peaks in our discussions. The reason for this is because in the analysis of a complex mixture (like DOM) with direct injection through electrospray ionization (ESI), changes in the intensity of peaks for a specific set of compounds is not only a function of concentration, but is also affected by charge competition in the ESI with other background compounds. As a result, significant changes in the abundance of one set of compounds will also affect the observed intensity of peaks for other compounds.

\subsubsection{Kendrick mass analysis}

Kendrick mass analysis (Hughey et al., 2001; Kendrick, 1963) was used to identify DOS formulas that can be formed by adding each of the following groups to a reactant formula: $\mathrm{H}_{2} \mathrm{~S}, \mathrm{H}_{2} \mathrm{~S}_{2}$, $\mathrm{H}_{2} \mathrm{SO}, \mathrm{H}_{2} \mathrm{SO}_{2}$, and $\mathrm{H}_{2} \mathrm{SO}_{3}$. In this calculation, we first rescaled the IUPAC masses (where the ${ }^{12} \mathrm{C}$ atomic mass is defined as exactly $12 \mathrm{Da}$ ) for all detected molecular formulas to the Kendrick mass scale with respect to $\mathrm{H}_{2} \mathrm{~S}, \mathrm{H}_{2} \mathrm{~S}_{2}, \mathrm{H}_{2} \mathrm{SO}, \mathrm{H}_{2} \mathrm{SO}_{2}$, or $\mathrm{H}_{2} \mathrm{SO}_{3}$. For example, rescaling with respect to $\mathrm{H}_{2} \mathrm{~S}$ is represented as,

Kendrick mass $=$ IUPAC mass $\times(34 / 33.987721)$

where the values 34 and 33.987721 are the nominal (integer) and IUPAC masses of $\mathrm{H}_{2} \mathrm{~S}$, respectively. The Kendrick mass defect (KMD) was then calculated by subtracting the Kendrick mass of each formula from its nominal (integer) mass,

Kendrick mass $\operatorname{defect}(\mathrm{KMD})=($ Nominal mass - Kendrick mass $)$

In this example, formulas having the same chemical backbone but differing only by the number of $\mathrm{H}_{2} \mathrm{~S}$ groups will have identical $\mathrm{KMD}$ values (forming a $\mathrm{H}_{2} \mathrm{~S}$ homologous series). Analogous calculations were conducted by scaling the Kendrick mass with respect to $\mathrm{H}_{2} \mathrm{~S}_{2}$ for polysulfide addition, $\mathrm{H}_{2} \mathrm{SO}$ for sulfoxide formation, $\mathrm{H}_{2} \mathrm{SO}_{2}$ for sulfone formation, and $\mathrm{H}_{2} \mathrm{SO}_{3}$ for sulfonic acid formation. In all of these homologous series, we identified one DOM reactant formula and at least one DOS formula that had the same KMD value but only differed by one mass unit of $\mathrm{H}_{2} \mathrm{~S}, \mathrm{H}_{2} \mathrm{~S}_{2}, \mathrm{H}_{2} \mathrm{SO}, \mathrm{H}_{2} \mathrm{SO}_{2}$, or $\mathrm{H}_{2} \mathrm{SO}_{3}$.

2.3.2. Analysis of molecular formulas by two-dimensional correlation

Spatial variability of $\mathrm{CHO}$ and DOS molecular formulas was investigated using two-dimensional (2-D) correlation analysis according to Abdulla et al. (2013) using depth as the perturbation factor. For each pore water sample, we created a histogram of $\mathrm{H} / \mathrm{C}$ ratios for $\mathrm{CHO}$ or DOS formulas (i.e., $\mathrm{H} / \mathrm{C}$ ratio on the $\mathrm{x}$-axis and number of formulas on the $\mathrm{y}$-axis). The $\mathrm{H} / \mathrm{C}$ ratio ranged from 0.00 to 2.50 at increments of 0.01 . Synchronous $2-\mathrm{D}$ correlation was conducted on this $\mathrm{H} / \mathrm{C}$ matrix as described in Abdulla et al. (2013). Correlations with an $r^{2}$-value equal to or greater than 0.7 , and a $p$ value less than or equal to 0.05 were considered significant.

\section{Results and discussion}

\subsection{Total dissolved sulfide $\left(\sum \mathrm{H}_{2} \mathrm{~S}\right)$}

Bacterial sulfate reduction results in the production and accumulation of sulfide with depth in SBB sediments (Fig. 1). While the decrease in $\mathrm{SO}_{4}^{2-}$ concentration begins immediately below the sediment-water interface, significant $\Sigma \mathrm{H}_{2} \mathrm{~S}$ accumulation does not begin until sediment depths of $\sim 2 \mathrm{~cm}$ to $9 \mathrm{~cm}$. The observed lag between the decrease in sulfate and the accumulation of $\sum \mathrm{H}_{2} \mathrm{~S}$ agrees with previously reported results in SBB sediments (Reimers et al., 1996). With increasing depth, $\mathrm{\Sigma}_{2} \mathrm{~S}$ increases and reaches a maximum value of $6.25 \mathrm{mM}$ at $\sim 150 \mathrm{~cm}$ near the SMTZ. Below this depth $\Sigma \mathrm{H}_{2} \mathrm{~S}$ decreases to $<1 \mathrm{mM}$ at the base of the profile. Depth profiles of $\mathrm{\Sigma H}_{2} \mathrm{~S}$ in other anoxic sediments also show 
similar decreases in $\Sigma \mathrm{H}_{2} \mathrm{~S}$ below the SMTZ (e.g. Niewöhner et al., 1998, Chanton et al., 1987).

Pore water profiles from SBB sediments indicate that the vast majority of the $\Sigma \mathrm{H}_{2} \mathrm{~S}$ that is produced above the SMTZ $(\sim 125 \mathrm{~cm})$ is removed within the top $450 \mathrm{~cm}$ of the sediment column (Fig. 1). While much of this removal is likely due to pyrite $\left(\mathrm{FeS}_{2}\right)$ formation, it may also involve abiotic formation of organic sulfur compounds (e.g. Valisolalao et al., 1984; Sinninghe Damsté et al., 1989; Vairavamurthy and Mopper, 1987; De Graaf et al., 1992; Wakeham et al., 1995). The rate of pyrite formation is generally highest in the top few decimeters of SBB sediments where the availability of reducible iron is greatest (Reimers et al., 1996; Burdige, 2006; Raven et al., 2016a). However, sulfide removal is also evident below the SMTZ (Fig. 1). Pyrite formation is also known to occur at such depths where reducible iron oxides are no longer found, and a number of possible mechanisms may be responsible for this "deep" pyrite formation. These include the oxidation of FeS by $\mathrm{H}_{2} \mathrm{~S}$ (Rickard and Luther, 2006), and sulfide oxidation by the more refractory "structural" $\mathrm{Fe}(\mathrm{III})$ in clay mineral lattice sites followed by exchange of the $\mathrm{Fe}^{2+}$ that is produced by this reaction with pore water $\mathrm{Mg}^{2+}$ (see discussions in Leslie et al., 1990). Additionally, a small amount of deep pyrite could be formed through reaction with iron silicates (Raiswell et al., 1994). At the same time, removal of $\sum \mathrm{H}_{2} \mathrm{~S}$ throughout the depth profile may also involve abiotic formation of organic sulfur compounds, and consistent with this possibility, organic sulfur (protokerogen sulfur) concentrations showed a gradual increase with depth in SBB sediments and reached near-equivalent concentrations to pyrite sulfur below $200 \mathrm{~cm}$ (Raven et al., 2016a).

\subsection{FTICR-MS analysis}

As previously reported (Abdulla et al., 2018), 8842 unique formulas were identified in the 28 pore water samples analyzed by FTICR-MS. Of these formulas, dissolved organic nitrogen (DON) formulas represent the highest percentage (45\%) followed by DOS formulas (35\%), CHO-only formulas (31\%) and dissolved organic phosphorous (DOP) formulas (11\%). The relative number of both DON and DOS formulas increased with depth while the relative number of $\mathrm{CHO}$ formulas decreased with depth (Abdulla et al., 2018). DOP formulas showed no obvious depth trend, and were not investigated further. DON formulas are discussed in detail in Abdulla et al. (2018) while DOS and CHO formulas are discussed below.

\subsection{1. $\mathrm{CHO}$ formulas}

A van Krevelen diagram of all detected CHO compounds (2726 unique formulas from all 28 pore waters samples) (Fig. S1) shows that the majority of these formulas (63\%) fell in the region defined by Hertkorn et al. (2006) for carboxyl-rich alicyclic molecules (CRAM) and $26 \%$ fell in the region where most lipid-like compounds are observed (e.g. Sleighter and Hatcher, 2007; Abdulla et al., 2013). Examined as a function of depth, these CHO formulas show a clear shift in composition towards greater unsaturation (lower $\mathrm{H} / \mathrm{C}$ ) and oxygenation (higher $\mathrm{O} / \mathrm{C}$ ) with increasing depth (Fig. 2a-c). Table $\mathrm{S} 1$ also shows that lipid-like formulas $(\mathrm{H} /$ $\mathrm{C}=1.70-2.25 ; \mathrm{O} / \mathrm{C}=0.05-0.20)$ decreased with depth, while CRAM-like formulas $(\mathrm{H} / \mathrm{C}=0.70-1.70 ; \mathrm{O} / \mathrm{C}=0.10-0.60)$ increased with depth. For the three samples shown in Fig. 2, lipid-like CHO formulas decreased from $40 \%$ of the total number of $\mathrm{CHO}$ formulas at $0.25 \mathrm{~cm}$, to $15 \%$ at $172 \mathrm{~cm}$ ( middle of profile), and $3 \%$ at $432 \mathrm{~cm}$ (deepest sample), respectively. In contrast, molecular formulas that fell in the CRAM region increased from $34 \%$ of the total $\mathrm{CHO}$ formulas at $0.25 \mathrm{~cm}$ to $66 \%$ and $88 \%$ at $172 \mathrm{~cm}$ and $432 \mathrm{~cm}$, respectively.

To further examine these depth tends, we analyzed the complete set of 28 pore water samples using 2-D correlation analysis (Section 2.3.2.). Two regions of significant positive correlation (red color) were observed along the diagonal of the synchronous 2-D correlation diagram, at $\mathrm{H} / \mathrm{C}$ ratios between 1.75 and 2.00 (within the lipid-like region) and $0.75-1.73$ (upper part of the CRAM region) (Fig. 3a). This indicates that the number of molecular formulas with these $\mathrm{H} / \mathrm{C}$ ratios changed significantly with depth. The off-diagonal signal indicated a strong negative correlation (green color) between these two regions, consistent with the observation in Table S1 that the number of $\mathrm{CHO}$ formulas in the CRAM region increased with depth, while the number of $\mathrm{CHO}$ lipid-like formulas decreased with depth.
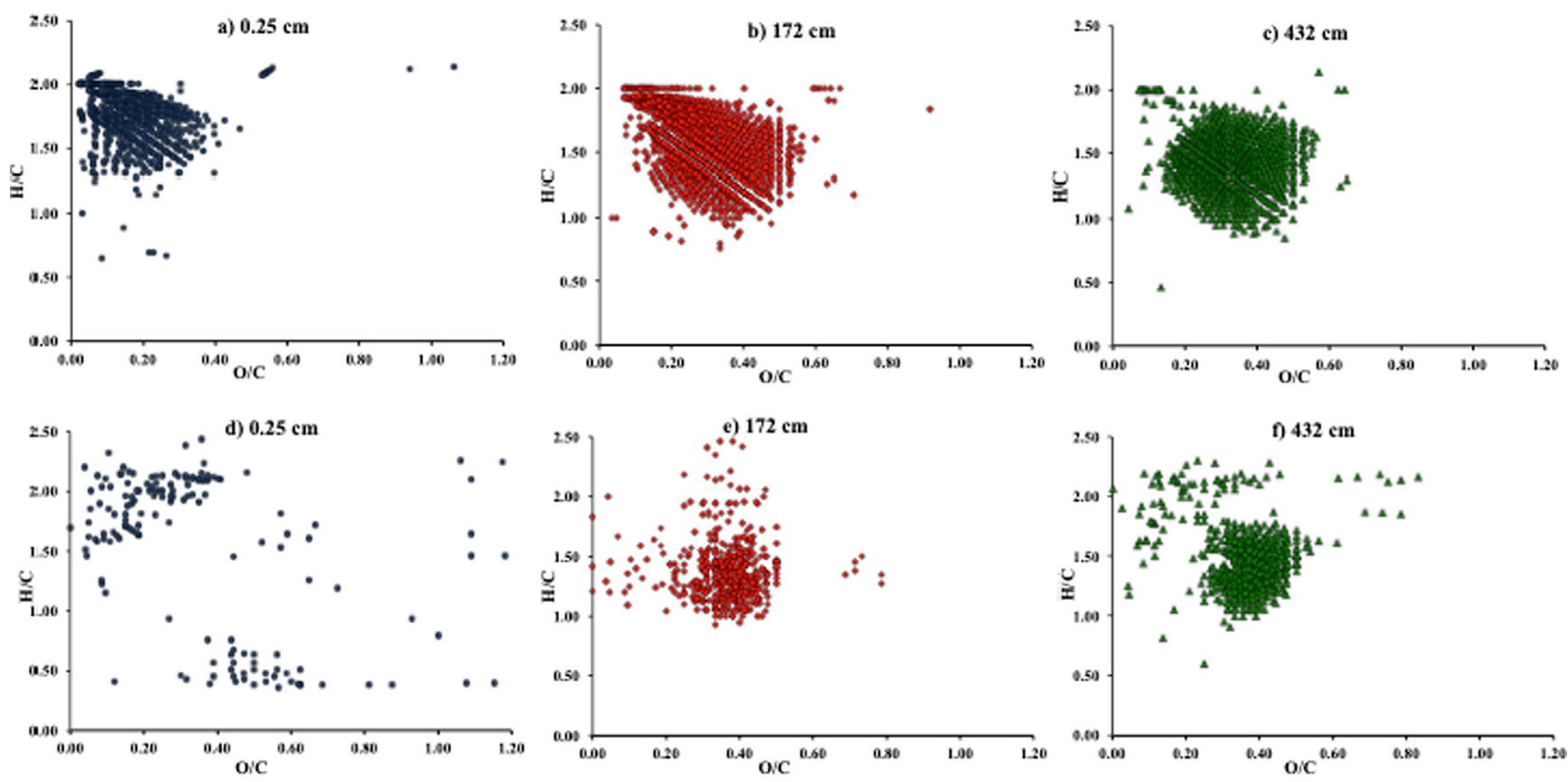

Fig. 2. van Krevelen diagrams of $\mathrm{CHO}$ formulas (a-c) and DOS formulas (d-f) detected in SBB pore waters at depths of $0.25 \mathrm{~cm}(\mathrm{a}, \mathrm{d}), 172 \mathrm{~cm}(\mathrm{~b}, \mathrm{e})$, and $432 \mathrm{~cm}$ (c, f). 

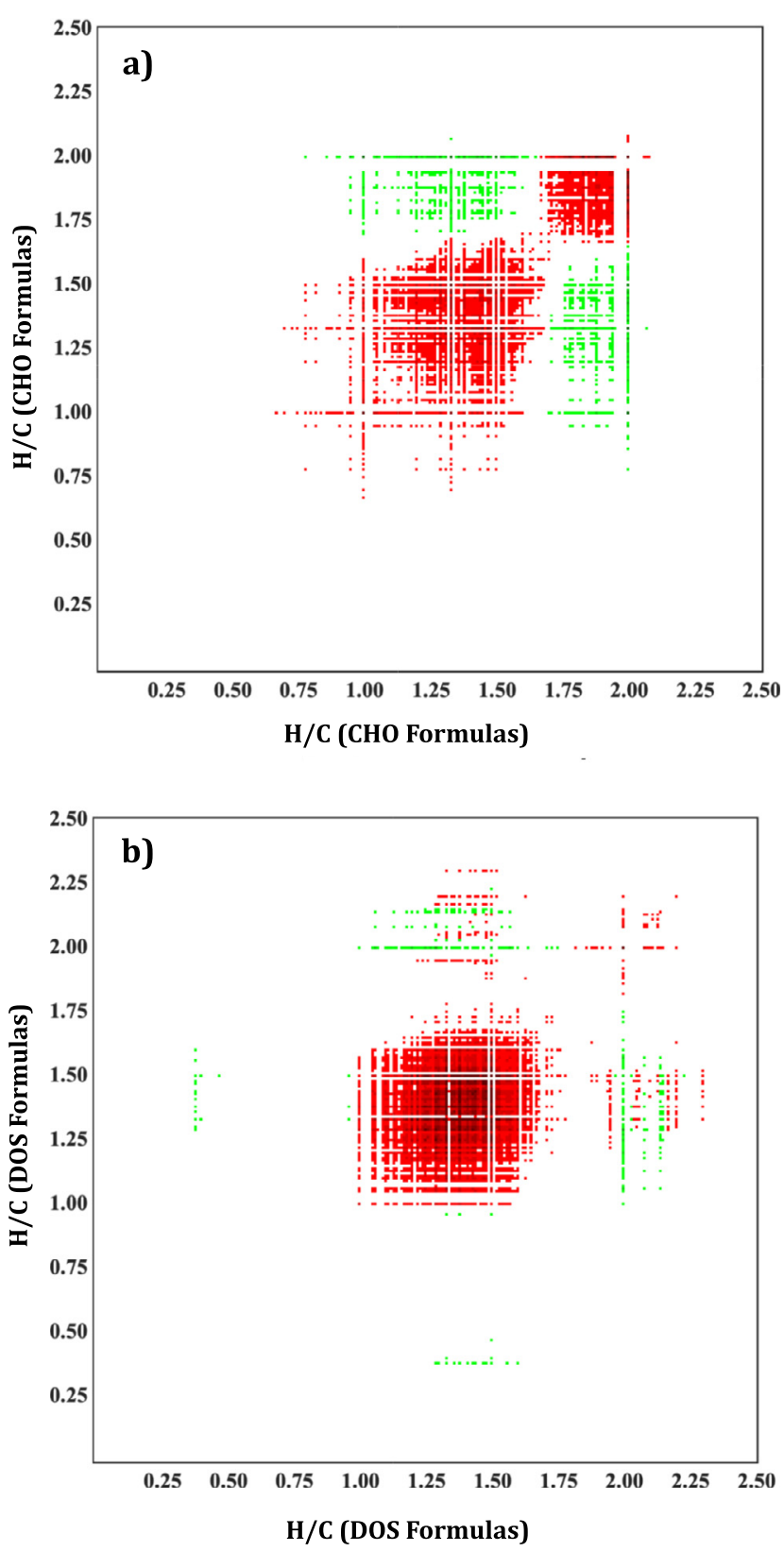

Fig. 3. 2-D correlation synchronous maps generated from the presence or absence of (a) individual CHO formulas, and (b) individual DOS formulas detected in the 28 pore water samples as a function of their $\mathrm{H} / \mathrm{C}$ ratio, using depth as the perturbation factor. Red dots indicate positive correlation while green dots indicate negative correlation, Higher color intensity indicates stronger correlation. The threshold for significant correlations was $r-$ values greater than or equal to 0.7 and $p<0.05$. (For interpretation of the references to color in this figure legend, the reader is referred to the web version of this article.)

\subsubsection{DOS formulas}

Dissolved organic sulfur (DOS) formulas showed greater variability in $\mathrm{H} / \mathrm{C}$ and $\mathrm{O} / \mathrm{C}$ ratios relative to $\mathrm{CHO}$ formulas (compare Figs. S1 and S2). Most of these formulas fell in the CRAM-like region (67\%; from hereon referred to as S-CRAM) while $15 \%$ fell in the lipid-like region. The number of formulas that fell in the lipid-like region decreased from $29 \%$ of the total DOS formulas at the sediment surface $(0.25 \mathrm{~cm})$ to $3 \%$ and $6 \%$ at $172 \mathrm{~cm}$ and $432 \mathrm{~cm}$, respectively (Fig. 2d-f, Table S1). In contrast, the number of DOS formulas that fell in the CRAM region increased from 13\% at $0.25 \mathrm{~cm}$ to $76 \%$ at $172 \mathrm{~cm}$ and $82 \%$ at $432 \mathrm{~cm}$. Similar to the CHO formulas, 2-D correlation analysis of individual DOS formulas
(Fig. 3b) showed substantial changes with depth in the CRAM region $(\mathrm{H} / \mathrm{C} 1.00-1.65)$ and some changes with depth in the region between $\mathrm{H} / \mathrm{C}$ 1.90-2.30 (S-lipid-like region). The off-diagonal correlations suggest that the $\mathrm{S}$-lipid-like region consists of two sets of formulas with different depth-dependent variability. The first set showed a negative correlation with the S-CRAM region (green horizontal or vertical lines in the off-diagonal regions), while the second set showed a positive correlation with the S-CRAM region (red horizontal or vertical lines in the off-diagonal regions). As seen in Table S1, the number of S-CRAM formulas increased with sediment depth, the first set of lipid-like formulas decreased, and the second set increased.

\subsection{Abiotic formation of dissolved organic sulfur}

The $\mathrm{pH}$ of SBB sediment pore waters is slightly basic (Reimers et al., 1996). Therefore, nucleophilic addition reactions, where a strong nucleophile reacts with an electrophilic $\pi$ bond of an organic molecule to form a new $\mathrm{C}-\mathrm{S}$ bond, may play a major role in abiotic formation of reduced organic sulfur compounds (e.g. Aizenshtat et al., 1995). The average double bond equivalent (DBE) of DOS and CHO formulas in SBB sediment pore waters suggests that such sulfurization reactions may occur here. DBE values of both DOS and CHO formulas are roughly constant with depth, equaling $6.8 \pm 0.1$ and $7.7 \pm 0.1$, respectively (Fig. $4 \mathrm{a}$ ). Thus on average, DOS formulas have roughly one fewer double bonds than $\mathrm{CHO}$ formulas in these sediments. This constant offset in DBE values and the increase with depth in the relative and absolute number of DOS formulas as compared to $\mathrm{CHO}$ formulas (Fig. 4b, Table S1) are consistent with the formation of new DOS compounds through bisulfide addition to $\mathrm{CHO}$ compounds.

A recent study of DOS compounds in Cariaco Basin anoxic sediments using compound-specific $S$ isotope analysis also suggested addition of bisulfide $\left(\mathrm{HS}^{-}\right)$as a mechanism for DOS formation (Raven et al., 2015). However, they found that $\mathrm{HS}^{-}$addition alone was insufficient to explain the observed $\delta^{34} S$ values, and hypothesized the occurrence of at least one additional sulfurization pathway. Here, we investigate the mechanisms of nucleophilic addition reactions of the two main inorganic sulfur substances that have been shown to act as strong nucleophiles, bisulfide $\left(\mathrm{HS}^{-}\right)$and polysulfide $\left(\mathrm{HS}_{\mathbf{x}}^{-}\right.$) (LaLonde et al., 1987; Vairavamurthy and Mopper, 1987; Aizenshtat et al., 1995).

\subsubsection{Bisulfide $\left(\mathrm{HS}^{-}\right)$pathway}

Bisulfide acts as a strong nucleophile by attacking the double bond (e.g. $\mathrm{C}=\mathrm{C}$ or $\mathrm{C}=\mathrm{O}$ ) in an unsaturated DOM compound forming new $\mathrm{S}-\mathrm{C}$ and $\mathrm{H}-\mathrm{C} / \mathrm{H}-\mathrm{O}$ covalent bonds (Fig. 5). Through KMD analysis (Section 2.3.1) of all of the detected DOM formulas, we identified $1960 \mathrm{H}_{2} \mathrm{~S}$ homologous series in SBB pore waters (Fig. 6). While the majority of these $\mathrm{H}_{2} \mathrm{~S}$ homologous series involved only one $\mathrm{H}_{2} \mathrm{~S}$ addition, $22 \%$ of the homologous series involved two $\mathrm{H}_{2} \mathrm{~S}$ additions (e.g., see the dashed circle in Fig. $6 \mathrm{c}$ ). This indicates that some reactive DOM compounds were involved in two sequential $\mathrm{H}_{2} \mathrm{~S}$ addition reactions, potentially involving bisulfide additions across two double bonds in their chemical structures. A van Krevelen diagram of the initial reactant and product DOS formulas that resulted from this $\mathrm{HS}^{-}$pathway (Fig. 7) shows that the DOS formulas have higher $\mathrm{H} / \mathrm{C}$ ratios relative to their initial reactant formulas, which is expected as a result of adding the two $\mathrm{H}$ atoms of $\mathrm{H}_{2} \mathrm{~S}$ per bisulfide addition to each molecule. Fig. $7 \mathrm{a}$ also indicates that the majority of the reactant and DOS formulas that are involved in the $\mathrm{HS}^{-}$pathway fall in the CRAM region.

\subsubsection{Polysulfide $\left(H S_{x}^{-}\right)$pathway}

Like bisulfide, polysulfide $\left(\mathrm{HS}_{\mathrm{x}}^{-}\right)$is also a highly reactive nucleophile; it can attack the $\mathrm{C}=\mathrm{C}$ double bond creating two new single 

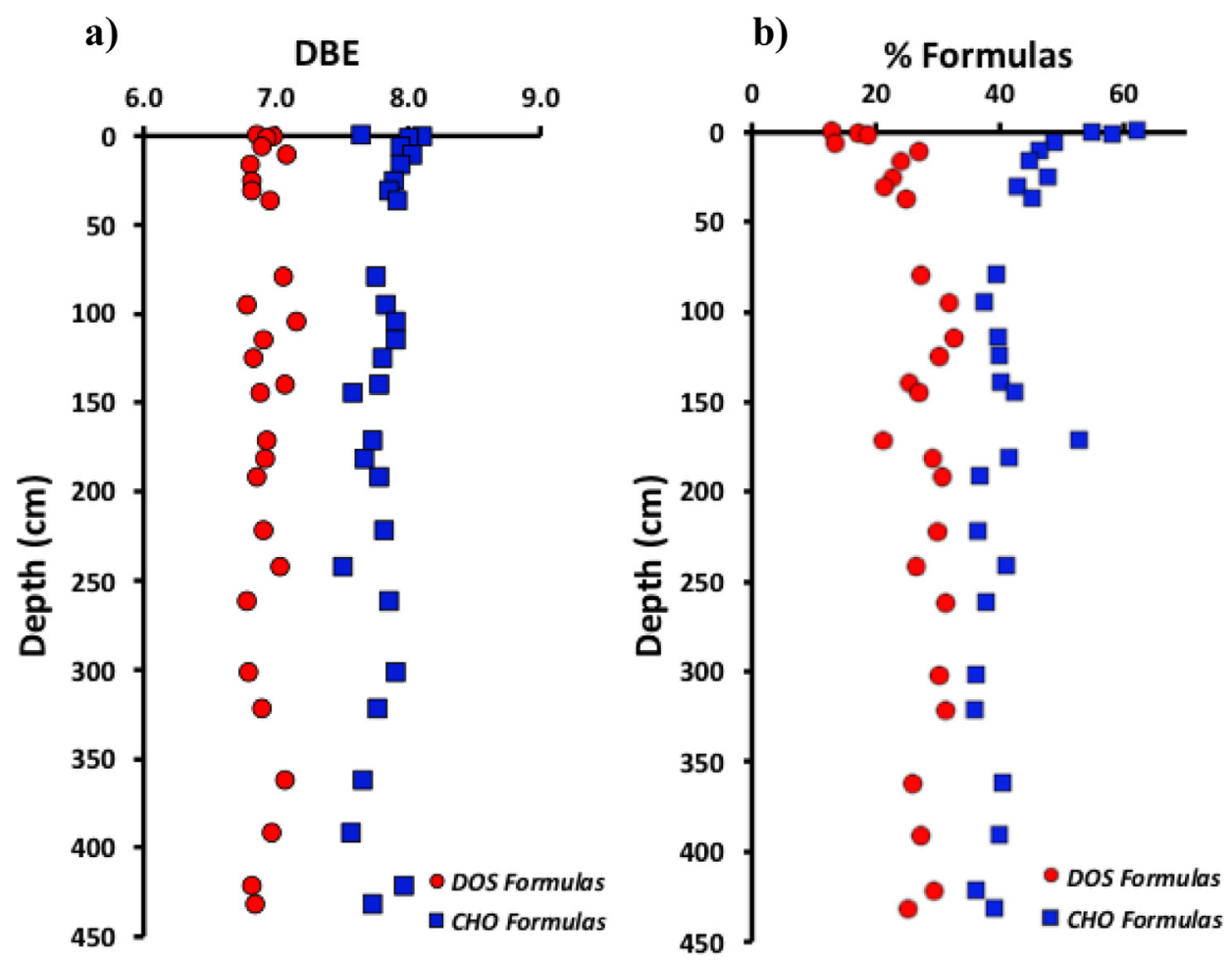

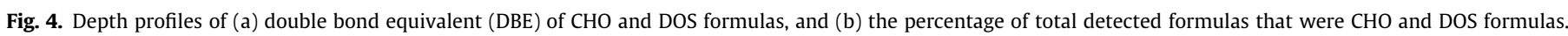

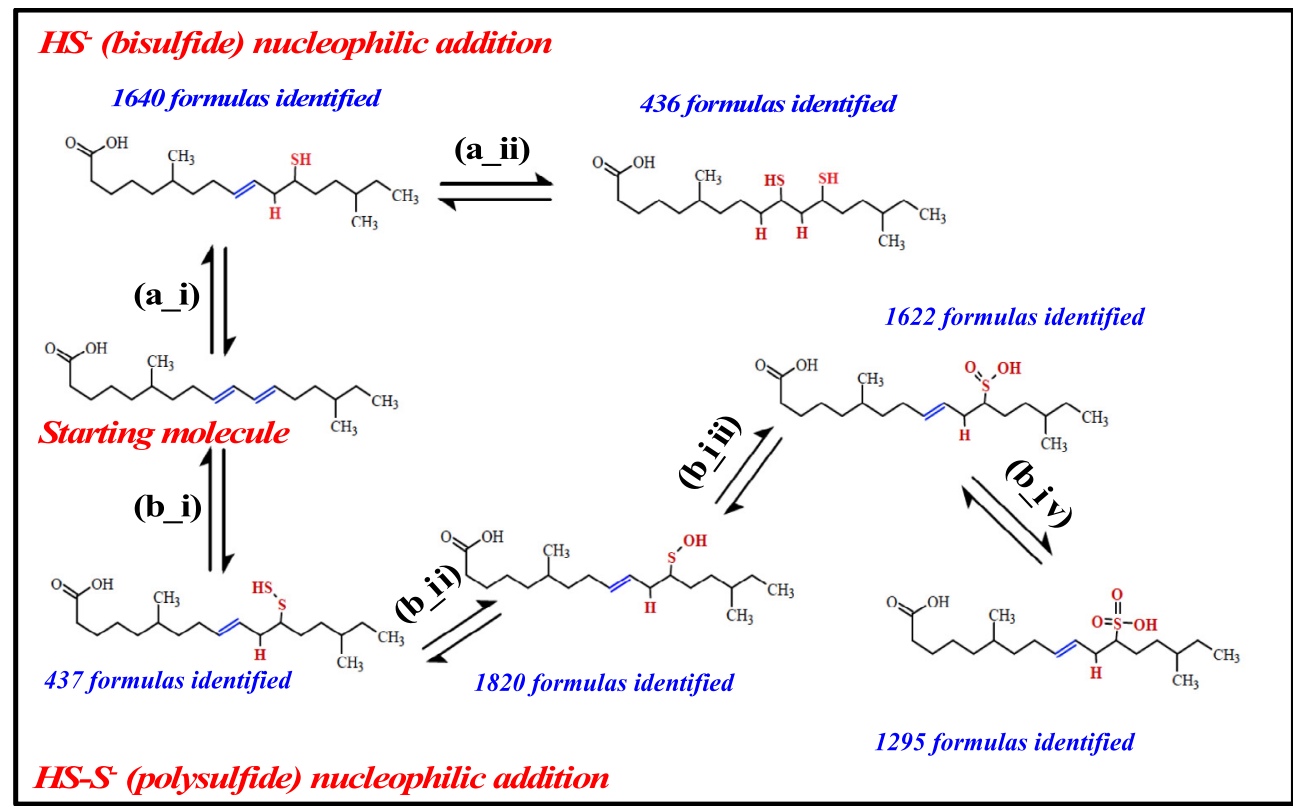

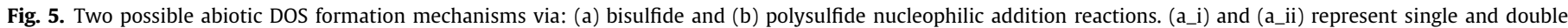
nucleophilic additions of $\mathrm{H}_{2} \mathrm{~S}$, respectively. (b_i), (b_ii), (b_iii) and (b_iv) are nucleophilic addition reactions of $\mathrm{HS}_{\mathrm{x}}^{-}, \mathrm{H}_{2} \mathrm{SO}_{2} \mathrm{H}_{2} \mathrm{SO}_{2}$ and $\mathrm{H}_{2} \mathrm{SO}_{3}$, respectively.

covalent bonds (HS-S-C and $\mathrm{H}-\mathrm{C}$ ), as illustrated in Fig. 5. After this addition, at slightly basic $\mathrm{pH}$, the $\mathrm{HS}^{-}$group can be replaced with a $\mathrm{OH}^{-}$group, forming a $\mathrm{HO}-\mathrm{S}-\mathrm{C}$ bond, or sulfoxide functional group (Fig. 5). This product is readily oxidized to a sulfone or sulfonic acid in the presence of oxidizing agents such as hydrogen peroxide and $\mathrm{OH}$ radical, which have both shown to form in anoxic sediments by biotic and abiotic processes (e.g. AbeleOeschger et al., 1994; Lin et al., 2005; Page et al., 2013). Organic sulfoxide may also form through the bisulfide pathway, but is likely less kinetically favored relative to the polysulfide pathway.
This is because the oxidation step to form sulfoxide by hydroxyl radical requires formation of a $2 \sigma / 1 \sigma^{*}$ three-electron bonded radical cation (-S: ${ }^{+}$S-) transition state (e.g. Schoeneich et al., 1993; Miller et al., 1996).

To assess the significance of the polysulfide reaction pathway in SBB sediments, we used KMD calculations as described in Section 2.3.1, but instead of scaling the Kendrick mass with respect to $\mathrm{H}_{2} \mathrm{~S}$, we scaled the masses with respect to $\mathrm{H}_{2} \mathrm{~S}_{2}$ for polysulfide addition, $\mathrm{H}_{2} \mathrm{SO}$ for sulfoxide formation, $\mathrm{H}_{2} \mathrm{SO}_{2}$ for sulfone formation, and $\mathrm{H}_{2} \mathrm{SO}_{3}$ for sulfonic acid formation (reactions b_i through 

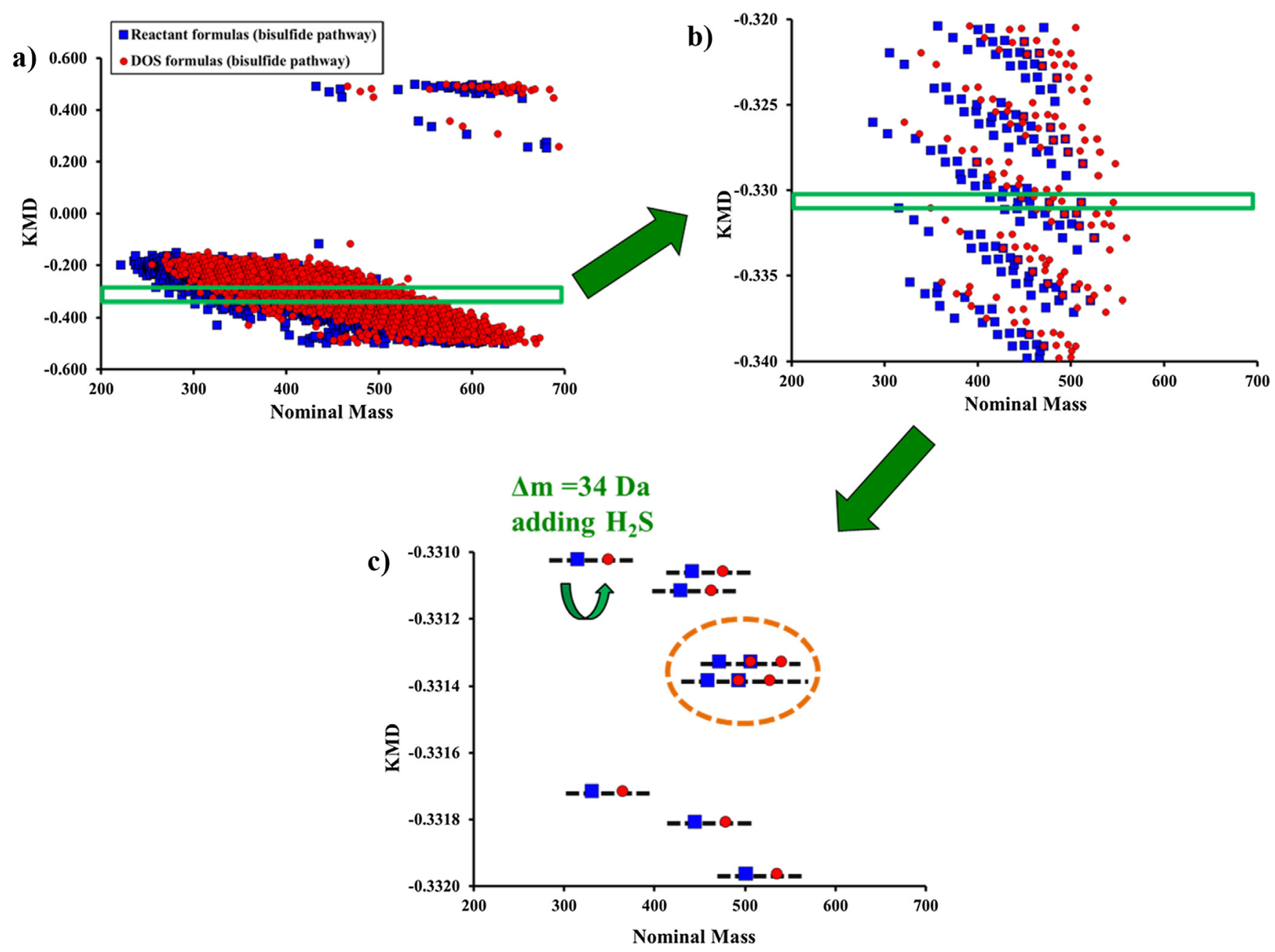

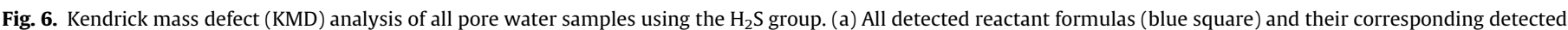

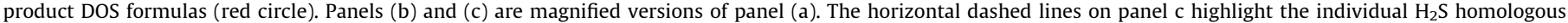

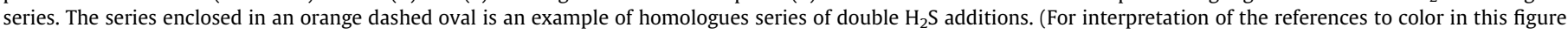
legend, the reader is referred to the web version of this article.)

b_iv in Fig. 5, respectively). Using this approach, we identified the following numbers of homologous series: 437 for $\mathrm{H}_{2} \mathrm{~S}_{2}, 1820$ for $\mathrm{H}_{2} \mathrm{SO}, 1622$ for $\mathrm{H}_{2} \mathrm{SO}_{2}$ and 1295 for $\mathrm{H}_{2} \mathrm{SO}_{3}$ (see Fig. 5). A van Krevelen diagram of the reactant formulas and their corresponding product DOS formulas that can be formed from the different polysulfide $\left(\mathrm{HS}_{\mathrm{x}}^{-}\right.$) pathway reactions (Fig. 8) shows that the DOS formulas shift to higher $\mathrm{H} / \mathrm{C}$, and in some cases to higher $\mathrm{O} / \mathrm{C}$ ratios, relative to their reactant formula counterparts, which is expected due to addition of $\mathrm{H}$ and $\mathrm{O}$ atoms to the $\mathrm{CHO}$ formulas through this sulfur addition pathway.

\subsubsection{Differentiating between bisulfide and polysulfide pathways}

Approximately $70 \%$ of all unique DOS formulas detected in the 28 pore water samples could be assigned as products of the two sulfur incorporation pathways. Of these 2124 DOS formulas, $87 \%$ could be produced by either or both sulfurization pathways, while $8 \%$ and $5 \%$ of these abiotic DOS formulas could only be produced by the polysulfide and bisulfide pathways, respectively. This large overlap may stem from the fact that we only used the soft ionization full scan mode on the FTICR-MS, which does not provide information about molecular structure, limiting our ability to differentiate which of these DOS formulas is explicitly produced through a specific pathway (to do so requires the use of tandem mass analysis (MS/MS) along with FTICR-MS, which was beyond the scope of this study). Nonetheless, plotting these classified for- mulas on a van Krevelen diagram (Fig. S3) demonstrates that 90\% of the DOS formulas that are only generated by the bisulfide pathway have low $\mathrm{O} / \mathrm{C}$ ratios (less than 0.4 ), while DOS formulas that were only produced by the polysulfide pathway plot across a broader range of $\mathrm{O} / \mathrm{C}$ as well as $\mathrm{H} / \mathrm{C}$ ratios. The relatively higher $\mathrm{O} / \mathrm{C}$ for distinct polysulfide formulas is expected, as additional oxygen atoms can be added through this specific mechanism.

Detecting distinct formulas that are products of each DOS production pathway supports our argument that both pathways may occur in anoxic sediments of SBB. While the bisulfide nucleophilic addition mechanism has been examined in a number of both laboratory- and field-based studies (e.g. Valisolalao et al., 1984; Sinninghe Damsté et al., 1989; Vairavamurthy and Mopper, 1987; Wakeham et al., 1995), only a handful of studies have looked at the polysulfide pathway and the production of oxygenated organosulfur compounds in anoxic sediments. However, Vairavamurthy et al. (1994) observed that sulfonates accounted for $\sim 20-40 \%$ of the total organic sulfur in near surface anoxic sediments. Examining long $(\sim 100 \mathrm{~m})$ anoxic sediment cores from the Peruvian margin by X-ray absorption near edge structure (XANES) spectroscopy, Eglinton et al. (1994) detected a broad array of organosulfur oxidation states (sulfonates, sulfoxides and sulfides), leading them to suggest that abiotic sulfur incorporation may involve a variety of intermediates. Also using XANES spectroscopy, Zhu et al. (2014) found comparable amounts of highly oxidized and 


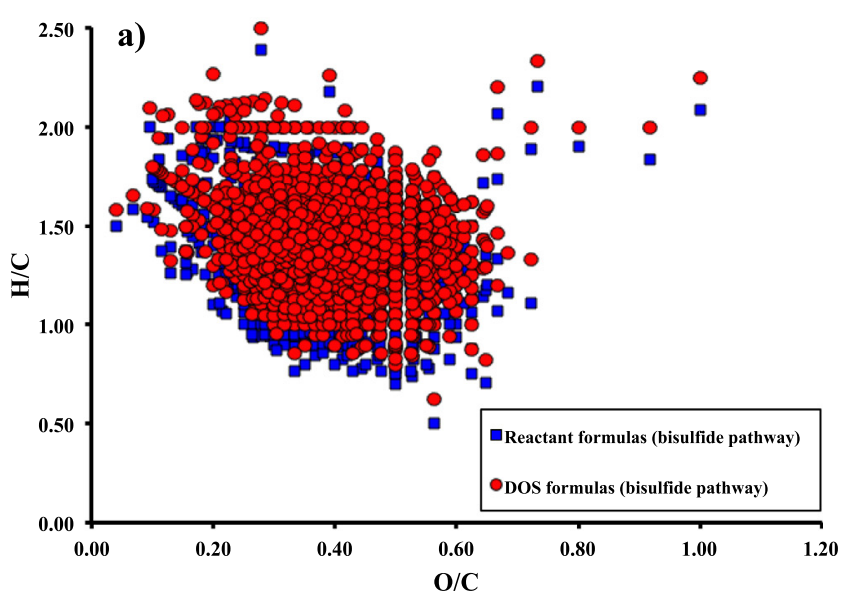

b)

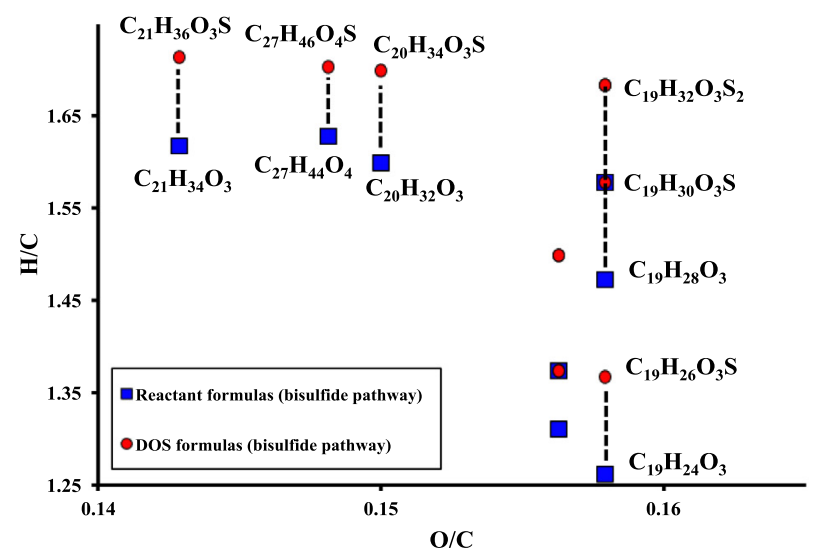

Fig. 7. (a) van Krevelen diagram of detected $\mathrm{CHO}$ formulas (blue square) that were identified as reactants in the bisulfide $\left(\mathrm{HS}^{-}\right)$nucleophilic addition reaction, and their corresponding product DOS formulas detected in our samples (red circle). (b) Magnified van Krevelen diagram illustrating some example abiotic nucleophilic addition reactions involving $\mathrm{HS}^{-}$. (For interpretation of the references to color in this figure legend, the reader is referred to the web version of this article.)

reduced organosulfur species in the humic acid fraction of sediments in Jiaozhou Bay, China. These findings agree with our detection here of both oxygenated and non-oxygenated organosulfur intermediates (Fig. 5).

\subsection{Reactant DOM formulas}

Of the formulas identified as reactants in the two abiotic sulfurization pathways, $64 \%$ were $\mathrm{CHO}$ formulas and $34 \%$ were DON formulas. Plotting these two reactant formula classes on a van Krevelen diagram (Fig. S4) shows that the $\mathrm{CHO}$ formulas occur over a wider $\mathrm{H} / \mathrm{C}$ range $(\mathrm{H} / \mathrm{C}=0.70-2.00)$ than the DON formulas $(\mathrm{H} /$ $\mathrm{C}=0.88-1.55$ ). Most of these $\mathrm{CHO}$ formulas (85\%) fell in the CRAM region, with the remaining $15 \%$ falling in the lipid-like region. The occurrence of lipid-like formulas involved in abiotic sulfurization reactions is consistent with previous studies that detected lipid sulfurization during early diagenesis in anoxic to mixed-redox sediments (e.g. Valisolalao et al., 1984; Sinninghe Damsté et al., 1989; Wakeham et al., 1995). However, our study indicates that lipid sulfurization only appears to account for a small fraction of the total number of sulfurization reactions occurring in anoxic SBB pore waters, and that instead, most reactions likely involve $\mathrm{CHO}$ formulas that fall within the CRAM region on a van Krevelen diagram (Fig S4). This is consistent with other recent FTICR-MS studies of

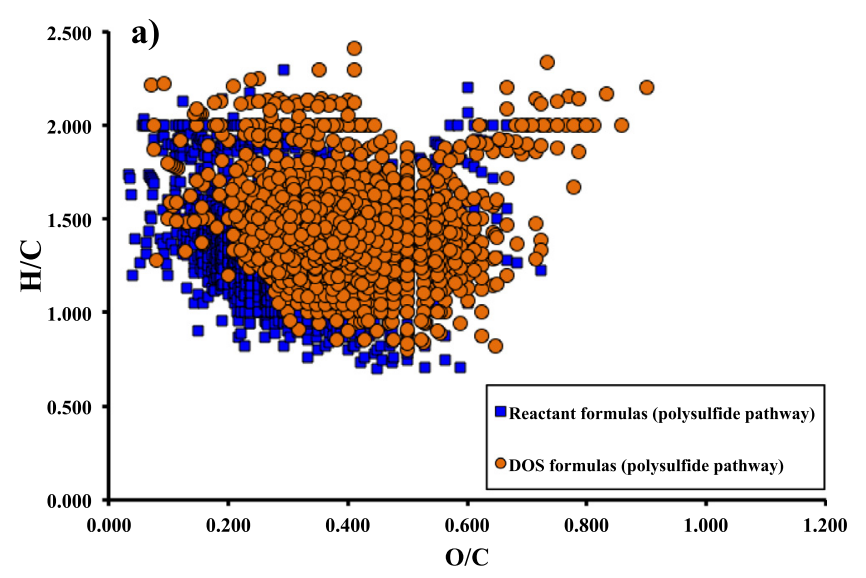

b)

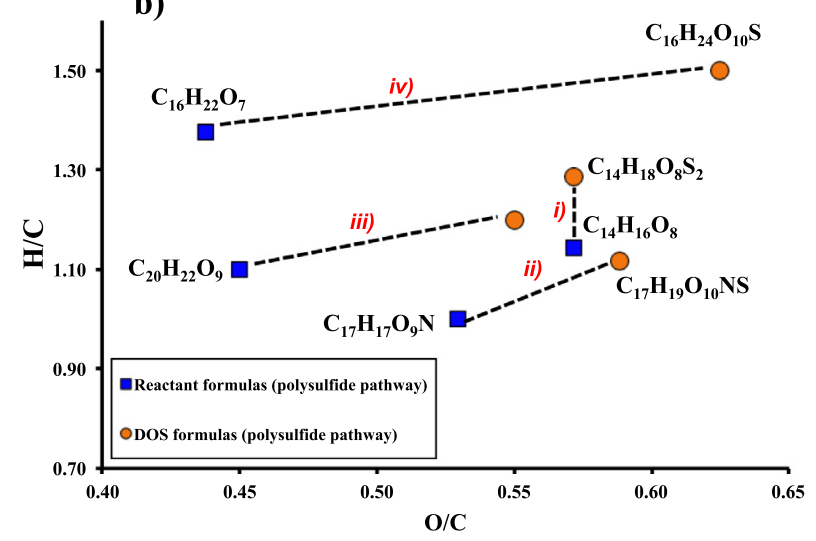

Fig. 8. (a) van Krevelen diagram of detected $\mathrm{CHO}$ formulas (blue square) that were identified as reactants in polysulfide $\left(\mathrm{HS}_{\mathrm{x}}^{-}\right)$nucleophilic addition reactions and their counterpart detected DOS formulas (brown circle). (b) Magnified van Krevelen diagram illustrating examples of: (i) $\mathrm{H}_{2} \mathrm{~S}_{2}$, (ii) $\mathrm{H}_{2} \mathrm{SO}$, (iii) $\mathrm{H}_{2} \mathrm{SO}_{2}$, and (iv) $\mathrm{H}_{2} \mathrm{SO}_{3}$ addition reactions. (For interpretation of the references to color in this figure legend, the reader is referred to the web version of this article.)

hydrothermal fluids and wetland sediment pore waters that also show that most abiotic sulfurization involves reactions with such CHO-CRAM formulas (Gomez-Saez et al., 2016; Poulin et al., 2017).

Similar to the $\mathrm{CHO}$ reactant formulas, $97 \%$ of the DON reactant formulas clustered in the middle of the CRAM region (Fig. S4). Comparing these DON reactant formulas to the deaminated peptide formulas that were detected in the same pore water samples (Abdulla et al., 2018), we find that $\sim 20 \%$ of these DON reactant formulas are also deaminated peptide formulas. This illustrates that some deaminated peptides may undergo further diagenetic alteration in the presence of sulfide. It also highlights the fact that sulfurization reactions in SBB pore waters are not limited to $\mathrm{CHO}$ formulas and also involve a wide variety of compounds including nitrogen-containing DOM compounds. This latter point agrees with laboratory sulfurization experiments which show that abiotic sulfur incorporation reactions are non-selective and occur with a wide variety of DOM compounds including DON compounds (Pohlabeln et al., 2017; Gomez-Saez et al., 2017).

\subsection{Geochemical implications of abiotic formation of DOS}

With the exception of the top $\sim 2 \mathrm{~cm}$, the DOS formulas produced by the bisulfide and polysulfide pathways described above represent $\sim 80 \%$ of all DOS formulas detected in SBB sediment pore waters (Fig. S5). The lower percentage of such DOS formulas near the sediment surface may be attributed to the high concentration 
of reactive iron near the surface that competes with reactive DOM compounds for reduced inorganic sulfur species (Canfield et al., 1992, 1996; Werne et al., 2003). If CRAM is indeed an important reactant in DOS formation, low levels of CRAM near the sediment-water interface (Fox et al., 2018) could also explain this observation.

Sulfurization of DOM in anoxic sediment pore waters is expected to alter the geochemical reactivity of the precursor compounds. For example, it may enhance adsorption of some sulfurized organic compounds to sediment particles relative to their precursor compounds. The increase with depth of protokerogen sulfur in SBB sediments (Raven et al., 2016a) supports this possibility as do observations in the Cariaco Basin water column which show that sulfur can be incorporated abiotically into sinking particulate organic matter on timescales of days (Raven et al., 2016b). All told, if the abiotic formation of DOS in anoxic sediment pore waters does play a role in the formation of sulfur-rich kerogen, these sulfurization reactions may play a key role in enhancing organic matter preservation in sulfidic sediments (e.g. Sinninghe Damsté and De Leeuw, 1990; Werne et al., 2004).

On the other hand, the production of DOS compounds in anoxic sediment pore waters could also lead to a benthic flux of DOS to the water column. In a recent study, Pohlabeln et al. (2017) estimated that the flux of DOS from sulfidic sediments could range from 30 to $200 \mathrm{Tg}$ DOS per year, and concluded that it may be one order of magnitude larger than the riverine DOS flux. While we did not measure the benthic flux of DOS compounds from SBB sediments, our past work has shown that SBB sediments are a source of CRAM-like material to the water column (Fox et al., 2018). As the majority of the DOS formulas we detected fall in the CRAM region, it is likely that this S-CRAM material is a part of the CRAM-like pool of compounds that escape from SBB sediments into the water column.

\section{Summary and conclusion}

Using FTICR-MS analyses, we investigated the abiotic formation of DOS in anoxic sediments of SBB. Nucleophilic addition reactions involving bisulfide $\left(\mathrm{HS}^{-}\right.$) and polysulfide $\left(\mathrm{HS}_{\mathrm{x}}^{-}\right.$) may account for $\sim 70 \%$ of all DOS formulas detected in SBB pore waters. The occurrence of these reactions may also explain the formation of oxidized organic sulfur species (sulfoxides, sulfones, and sulfonic acid) in anoxic pore waters, which may then explain the broad range of oxidation states of organosulfur compounds buried in anoxic sediments previously detected by XANES spectroscopy (Eglinton et al., 1994; Vairavamurthy et al., 1994; Zhu et al., 2014).

Our results and those of others (Gomez-Saez et al., 2016; Poulin et al., 2017; Gomez-Saez et al., 2017) reveal high sulfurization reactivity of many of the $\mathrm{CHO}$ and DON formulas that fall in the CRAM region on a van Krevelen diagram, and this group of formulas could be responsible for the formation of a major fraction of organosulfur compounds in anoxic and sulfidic sediments. If these DOS products are precursors of sulfur-containing protokerogen, they may play a key role in enhancing organic preservation in sulfidic sediments. At the same time, the apparent production of SCRAM formulas in SBB sediment pore waters makes anoxic sediments a potential source of S-CRAM to the open ocean.

\section{Acknowledgments}

We thank the captain and crew of $R / V$ Robert Gordon Sproul and $R / V$ New Horizon, and SIO marine technicians L. Ellet and M. Donohue for their expertise and support in the field. We also thank the OSU Marine Sediment Sampling Group and D. Hubbard for providing and operating coring equipment, and for general support in the field. J. Bleakney, A. Gerretson, P. Tennis, H. Li, K. Cada, A. Grose, B.
Riegel, G. Paris, and E. Harrison provided assistance in the field and in the laboratory. We would like also to thank Ann Pearson (AE) and the two reviewers Morgan Raven and Gonzalo Gomez-Saez for their detailed comments and suggestions. We are grateful to the staff at the COSMIC (College of Sciences Major Instrumentation Cluster) facility at Old Dominion University for their assistance with the FTICR-MS analyses. This material is based upon work supported by the National Science Foundation under grant numbers OCE-1155764 and OCE-1756686 to TK and OCE-1155562 and OCE-1756669 to DJB and OCE-1756672 to HAA.

\section{Appendix A. Supplementary material}

Supplementary data to this article can be found online at https://doi.org/10.1016/j.orggeochem.2019.05.009.

\section{Associate Editor-Ann Pearson}

\section{References}

Abdulla, H.A., Sleighter, R.L., Hatcher, P.G., 2013. Two dimensional correlation analysis of Fourier transform ion cyclotron resonance mass spectra of dissolved organic matter: a new graphical analysis of trends. Analytical Chemistry 85 (8), 3895-3902.

Abdulla, H.A., Burdige, D.J., Komada, T., 2018. Accumulation of deaminated peptides in anoxic sediments of Santa Barbara Basin. Geochimica et Cosmochimica Acta 223, 245-258.

Abele-Oeschger, D., Oeschger, R., Theede, H., 1994. Biochemical adaptations of Nereis diversicolor (Polychaeta) to temporarily increased hydrogen peroxide levels in intertidal sandflats. Marine Ecology Progress Series 106, 101-110.

Aizenshtat, Z., Krein, E.B., Murthy, Vairavamurthy, M.A., Goldstein, T.P., 1995. Role of sulfur in the transformations of sedimentary organic matter: a mechanistic overview, In: Vairavamurthy, M.A., Schoonen, M.A.A., Eglinton, T.I., Luther, G.W. III, Manowitz, B. (Eds.), Geochemical Transformations of Sedimentary Sulfur. American Chemical Society Symposium Series Symposium Series 612, pp. 1637.

Anderson, T.F., Pratt, L.M., 1995. Isotope evidence for the origin of organic sulfur and elemental sulfur in marine sediments. In: Vairavamurthy, M.A., Schoonen, M.A. A., Eglinton, T.I., Luther, G.W. III, Manowitz, B. (Eds.), Geochemical Transformations of Sedimentary Sulfur, American Chemical Society Symposium Series 612, p. 378-396.

Burdige, D.J., 2006. Geochemistry of Marine Sediments. Princeton University Press.

Burdige, D.J., Komada, T., Li, H.L., Magen, C., Chanton, J.P., 2016a. Modeling studies of dissolved organic matter cycling in Santa Barbara Basin (CA, USA) sediments. Geochimica et Cosmochimica Acta 195, 100-119.

Burdige, D.J., Komada, T., Magen, C., Chanton, J.P., 2016b. Carbon cycling in Santa Barbara Basin sediments: a modeling study. Journal of Marine Research 74, 133-159.

Canfield, D.E., Raiswell, R., Bottrell, S.H., 1992. The reactivity of sedimentary iron minerals toward sulfide. American Journal of Science 292 (9), 659-683.

Canfield, D.E., Lyons, T.W., Raiswell, R., 1996. A model for iron deposition to euxinic Black Sea sediments. American Journal of Science 296 (7), 818-834.

Chanton, J.P., Martens, C.S., Goldhaber, M.B., 1987. Biogeochemical cycling in an organic-rich coastal marine basin. 8. A sulfur isotopic budget balanced by differential diffusion across the sediment-water interface. Geochimica et Cosmochimica Acta 51 (5), 1201-1208.

Cline, J.D., 1969. Spectrophotometric determination of hydrogen sulfide in natural waters. Limnology and Oceanography 14, 454-458.

De Graaf, W., Sinninghe Damsté, J.S., De Leeuw, J.W., 1992. Laboratory simulation of natural sulphurization: I. Formation of monomeric and oligomeric isoprenoid polysulphides by low-temperature reactions of inorganic polysulphides with phytol and phytadienes. Geochimica et Cosmochimica Acta 56 (12), 4321-4328.

Dittmar, T., Koch, B., Hertkorn, N., Kattner, G., 2008. A simple and efficient method for the solid-phase extraction of dissolved organic matter (SPE-DOM) from seawater. Limnology and Oceanography: Methods 6 (6), 230-235.

Eglinton, T. Repeta, D. 2003. Organic matter in the contemporary ocean. In: Elderfield, H., Holland, H.D., Elderfield, H., Turekian, K.K. (Eds.), Treatise on Geochemistry: The Oceans and Marine Geochemistry 8. Elsevier, pp. 145-180.

Eglinton, T.I., Irvine, J.E., Vairavamurthy, A., Zhou, W., Manowitz, B., 1994. Formation and diagenesis of macromolecular organic sulfur in Peru margin sediments. Organic Geochemistry 22 (3-5), 781-799.

Filley, T.R., Freeman, K.H., Wilkin, R.T., Hatcher, P.G., 2002. Biogeochemical controls on reaction of sedimentary organic matter and aqueous sulfides in Holocene sediments of Mud Lake, Florida. Geochimica et Cosmochimica Acta 66 (6), 937 954.

Fox, C.A., Abdulla, H.A., Burdige, D.J., Lewicki, J.P., Komada, T., 2018. Composition of dissolved organic matter in pore waters of anoxic marine sediments analyzed by $1 \mathrm{H}$ nuclear magnetic resonance spectroscopy. Frontiers in Marine Science 5, 172 . 
Gomez-Saez, G.V., Niggemann, J., Dittmar, T., Pohlabeln, A.M., Lang, S.Q., Noowong, A., Pichler, T., Wörmer, L., Bühring, S.I., 2016. Molecular evidence for abiotic sulfurization of dissolved organic matter in marine shallow hydrothermal systems. Geochimica et Cosmochimica Acta 190, 35-52.

Gomez-Saez, G.V., Pohlabeln, A.M., Stubbins, A., Marsay, C.M., Dittmar, T. 2017. Photochemical alteration of dissolved organic sulfur from sulfidic porewater. Environmental Science \& Technology 51 (24), 14144-14154.

Hertkorn, N., Benner, R., Frommberger, M., Schmitt-Kopplin, P., Witt, M., Kaiser, K., Kettrup, A., Hedges, J.I., 2006. Characterization of a major refractory component of marine dissolved organic matter. Geochimica et Cosmochimica Acta 70 (12), 2990-3010.

Hughey, C.A., Hendrickson, C.L., Rodgers, R.P., Marshall, A.G., Qian, K., 2001. Kendrick mass defect spectrum: a compact visual analysis for ultrahighresolution broadband mass spectra. Analytical Chemistry 73 (19), 4676-4681.

Ingvorsen, K., Jorgensen, B.B., 1979. Combined measurement of oxygen and sulfide in water samples. Limnology and Oceanography 24, 390-393.

Kendrick, E., 1963. A mass scale based on $\mathrm{CH} 2=14.0000$ for high resolution mass spectrometry of organic compounds. Analytical Chemistry 35 (13), 2146-2154.

Kim, B.H., Gadd, G.M., 2008. Bacterial Physiology and Metabolism. Cambridge University Press.

Kind, T., Fiehn, O., 2007. Seven Golden Rules for heuristic filtering of molecular formulas obtained by accurate mass spectrometry. BMC Bioinformatics 8 (1), 105.

Koch, B.P., Dittmar, T., Witt, M., Kattner, G., 2007. Fundamentals of molecular formula assignment to ultrahigh resolution mass data of natural organic matter. Analytical Chemistry 79 (4), 1758-1763.

Komada, T., Burdige, D.J., Li, H.L., Magen, C., Chanton, J.P., Cada, A.K., 2016. Organic matter cycling across the sulfate-methane transition zone of the Santa Barbara Basin, California Borderland. Geochimica et Cosmochimica Acta 176, 259-278.

Krein, E.B., Aizenshtat, Z., 1995, Proposed thermal pathways for sulfur transformations in organic macromolecules: laboratory simulation experiments. In: Vairavamurthy, M.A., Schoonen, M.A.A., Eglinton, T.I., Luther, G.W. III, Manowitz, B. (Eds.), Geochemical Transformations of Sedimentary Sulfur. American Chemical Society Symposium Series Symposium Series 612, pp. 110-137.

LaLonde, R.T., Ferrara, L.M., Hayes, M.P., 1987. Low-temperature, polysulfide reactions of conjugated ene carbonyls: a reaction model for the geologic origin of S-heterocycles. Organic Geochemistry 11 (6), 563-571.

Leslie, B.W., Hammond, D.E., Berelson, W.M., Lund, S.P., 1990. Diagenesis in anoxic sediments from the California continental borderland and its influence on iron, sulfur, and magnetite behavior. Journal of Geophysical Research, Solid Earth 95 (B4), 4453-4470.

Lin, L.H., Hall, J., Lippmann, Pipke, J., Ward, J.A., Sherwood Lollar, B., DeFlaun, M., Rothmel, R., Moser, D., Gihring, T.M., Mislowack, B., Onstott, T.C., 2005. Radiolytic H2 in continental crust: nuclear power for deep subsurface microbial communities. Geochemistry, Geophysics, Geosystems 6 (7), Q07003.

Miller, B.L., Williams, T.D., Schöneich, C., 1996. Mechanism of sulfoxide formation through reaction of sulfur radical cation complexes with superoxide or hydroxide ion in oxygenated aqueous solution. Journal of the American Chemical Society 118 (45), 11014-11025.

Melendez-Perez, J.J., Martinez-Mejia, M.J., Barcellos, R.L., Fetter-Filho, A.F., Eberlin, M.N., 2018. A potential formation route for CHOS compounds in dissolved organic matter. Marine Chemistry 202, 67-72.

Nelson, B.C., Eglinton, T.I., Seewald, J.S., Vairavamurthy, M.A., Miknis, F.P., 1995. Transformations in organic sulfur speciation during maturation of Monterey Shale: constraints from laboratory experiments. In: Vairavamurthy, M.A. Schoonen, M.A.A., Eglinton, T.I., Luther, G.W. III, Manowitz, B. (Eds.), Geochemical Transformations of Sedimentary Sulfur. American Chemical Society Symposium Series Symposium Series 612, pp. 138-166.

Niewöhner, C., Hensen, C., Kasten, S., Zabel, M., Schulz, H.D., 1998. Deep sulfate reduction completely mediated by anaerobic methane oxidation in sediments of the upwelling area off Namibia. Geochimica et Cosmochimica Acta 62 (3), 455-464.

Page, S.E., Kling, G.W., Sander, M., Harrold, K.H., Logan, J.R., McNeill, K., Cory, R.M., 2013. Dark formation of hydroxyl radical in arctic soil and surface waters. Environmental Science \& Technology 47 (22), 12860-12867.

Pohlabeln, A.M., Gomez-Saez, G.V., Noriega-Ortega, B.E., Dittmar, T., 2017. Experimental evidence for abiotic sulfurization of marine dissolved organic matter. Frontiers in Marine Science 4, 364.

Poulin, B.A., Ryan, J.N., Nagy, K.L., Stubbins, A., Dittmar, T., Orem, W., Krabbenhoft, D. P., Aiken, G.R., 2017. Spatial dependence of reduced sulfur in Everglades dissolved organic matter controlled by sulfate enrichment. Environmental Science \& Technology 51 (7), 3630-3639.

Putschew, A., Schaeffer-Reiss, C., Schaeffer, P., Koopmans, M.P., De Leeuw, J.W., Lewan, M.D., Sinninghe Damsté, J.S., Maxwell, J.R., 1998. Release of sulfur-and oxygen-bound components from a sulfur-rich kerogen during simulated maturation by hydrous pyrolysis. Organic Geochemistry 29 (8), 1875-1890.
Raiswell, R., Canfield, D.E., Berner, R.A., 1994. A comparison of iron extraction methods for the determination of degree of pyritisation and the recognition of iron-limited pyrite formation. Chemical Geology 111 (1), 101-110.

Raven, M.R., Adkins, J.F., Werne, J.P., Lyons, T.W., Sessions, A.L., 2015. Sulfur isotopic composition of individual organic compounds from Cariaco Basin sediments. Organic Geochemistry 80, 53-59.

Raven, M.R., Sessions, A.L., Fischer, W.W., Adkins, J.F., 2016a. Sedimentary pyrite $\delta$ $34 \mathrm{~S}$ differs from porewater sulfide in Santa Barbara Basin: Proposed role of organic sulfur. Geochimica et Cosmochimica Acta 186, 120-134.

Raven, M.R., Sessions, A.L., Adkins, J.F., Thunell, R.C., 2016b. Rapid organic matter sulfurization in sinking particles from the Cariaco Basin water column. Geochimica et Cosmochimica Acta 190, 175-190.

Reemtsma, T., 2009. Determination of molecular formulas of natural organic matter molecules by (ultra-) high-resolution mass spectrometry: Status and needs. Journal of Chromatography A 1216 (18), 3687-3701.

Reimers, C.E., Ruttenberg, K.C., Canfield, D.E., Christiansen, M.B., Martin, J.B., 1996 Porewater $\mathrm{pH}$ and authigenic phases formed in the uppermost sediments of the Santa Barbara Basin. Geochimica et Cosmochimica Acta 60 (21), 4037-4057.

Rickard, D., Luther III, G.W., 2006. Metal sulfide complexes and clusters. Reviews in Mineralogy and Geochemistry 61 (1), 421-504.

Rossel, P.E., Bienhold, C., Boetius, A., Dittmar, T., 2016. Dissolved organic matter in pore water of Arctic Ocean sediments: Environmental influence on molecular composition. Organic Geochemistry 97, 41-52.

Schmidt, F., Elvert, M., Koch, B.P., Witt, M., Hinrichs, K.U., 2009. Molecular characterization of dissolved organic matter in pore water of continental shelf sediments. Geochimica et Cosmochimica Acta 73 (11), 3337-3358.

Schoeneich, C., Aced, A., Asmus, K.D., 1993. Mechanism of oxidation of aliphatic thioethers to sulfoxides by hydroxyl radicals. The importance of molecular oxygen. Journal of the American Chemical Society 115 (24), 11376-11383.

Seidel, M., Beck, M., Riedel, T., Waska, H., Suryaputra, I.G., Schnetger, B., Niggemann, J. Simon, M., Dittmar, T., 2014. Biogeochemistry of dissolved organic matter in an anoxic intertidal creek bank. Geochimica et Cosmochimica Acta 140, 418-434.

Sinninghe Damsté, J.S., De Leeuw, J.W., 1990. Analysis, structure and geochemica significance of organically-bound sulphur in the geosphere: State of the art and future research. Organic Geochemistry 16 (4-6), 1077-1101.

Sinninghe Damsté, J.S., Orr, W.L., 1990. Geochemistry of sulphur in petroleum systems. In: Orr, W.L., White, C.M. (Eds.), Geochemistry of Sulphur in Fossil Fuels. American Chemical Society Symposium Series Symposium Series 429, pp. $2-29$.

Sinninghe Damsté, J.S., Rijpstra, W.I.C., Kock-van Dalen, A.C., De Leeuw, J.W. Schenck, P.A., 1989. Quenching of labile functionalised lipids by inorganic sulphur species: Evidence for the formation of sedimentary organic sulphur compounds at the early stages of diagenesis. Geochimica et Cosmochimica Acta 53 (6), 1343-1355.

Sleighter, R.L., McKee, G.A., Liu, Z., Hatcher, P.G., 2008. Naturally present fatty acids as internal calibrants for Fourier transform mass spectra of dissolved organic matter. Limnology and Oceanography: Methods 6 (6), 246-253.

Sleighter, R.L., Hatcher, P.G., 2007. The application of electrospray ionization coupled to ultrahigh resolution mass spectrometry for the molecular characterization of natural organic matter. Journal of Mass Spectrometry 42 (5), 559-574.

Vairavamurthy, A., Mopper, K., 1987. Geochemical formation of organosulphur compounds (thiols) by addition of H2S to sedimentary organic matter. Nature 329 (6140), 623-625.

Vairavamurthy, A., Zhou, W., Eglinton, T., Manowitz, B., 1994. Sulfonates: A novel class of organic sulfur compounds in marine sediments. Geochimica et Cosmochimica Acta 58 (21), 4681-4687.

Valisolalao, J., Perakis, N., Chappe, B., Albrecht, P., 1984. A novel sulfur containing C35 hopanoid in sediments. Tetrahedron Letters 25 (11), 1183-1186.

van Dongen, B.E., Schouten, S., Sinninghe Damsté, J.S., 2003. Sulfurization of carbohydrates results in a sulfur-rich, unresolved complex mixture in kerogen pyrolysates. Energy \& Fuels 17 (4), 1109-1118.

Wakeham, S.G., Sinninghe Damsté, J.S., Kohnen, M.E., De Leeuw, J.W., 1995. Organic sulfur compounds formed during early diagenesis in Black Sea sediments. Geochimica et Cosmochimica Acta 59 (3), 521-533.

Werne, J.P., Lyons, T.W., Hollander, D.J., Formolo, M.J., Sinninghe Damsté, J.S., 2003 Reduced sulfur in euxinic sediments of the Cariaco Basin: sulfur isotope constraints on organic sulfur formation. Chemical Geology 195 (1), 159-179.

Werne, J.P., Hollander, D.J., Lyons, T.W., Sinninghe Damsté, J.S., 2004. Organic sulfur biogeochemistry: recent advances and future research directions. In: Amend, J. P., Edwards, K. J., Lyons, T. W., (Eds.), Sulfur Biogeochemistry: Past and Present, Issue 379. Geological Society of America, pp. 135-150.

Zhu, M.X., Chen, L.J., Yang, G.P., Huang, X.L., Ma, C.Y., 2014. Humic sulfur in eutrophic bay sediments: Characterization by sulfur stable isotopes and K-edge XANES spectroscopy. Estuarine, Coastal and Shelf Science 138, 121-129. 